\title{
Possible impacts of anthropogenic climate change to the upwelling in the South Brazil Bight
}

\author{
Mihael Machado de Souza ${ }^{1}$ (C) Moritz Mathis ${ }^{2} \cdot$ Bernhard Mayer $^{1} \cdot$ Maurício Almeida Noernberg $^{3}$. \\ Thomas Pohlmann ${ }^{1}$
}

Received: 16 December 2019 / Accepted: 4 May 2020 / Published online: 30 May 2020

(c) The Author(s) 2020

\begin{abstract}
Anthropogenic climate change is expected to strengthen upwelling events worldwide, driven by an increase of upwellingfavorable winds. However, Earth System Models (ESM) tend to underestimate regional processes due to their coarse grid resolution, which can lead to local biases. We use a high-resolution ocean model $\left(1 / 12^{\circ}\right)$ forced by results from the MaxPlanck-Institute-ESM to analyze the impact of the RCP8.5 emission scenario on the upwelling of South Atlantic Central Water (SACW) in the South Brazil Bight (SBB). We find a stronger Ekman forcing and a higher spread of SACW over the shelf, but this does not translate into higher vertical velocities at the bottom of the mixed-layer in the end of the century. The increased winds' effect is essentially balanced by an increase in water column stability due to the surface warming. This is particularly important during austral summer, when this process tends to weaken the upwelling. Vertical velocities decrease significantly along the shelf break. Here, the upwelling regime is governed by the Brazil Current (BC) and slight changes in transport induce large responses in upwelling strength. The consequences are increased sea surface temperatures over most of the shelf, although mitigated by the SACW upwelling and kept below global projections. However, temperatures decrease along Cabo Frio. In this region, shelf break upwelling dominates and is enhanced by a local increase in the BC transport. This highlights the importance of regional processes and, more specifically, of changes in the $\mathrm{BC}$ transport for the upwelling in the SBB.
\end{abstract}

Keywords Brazil current $\cdot$ Ekman transport $\cdot$ Potential vorticity $\cdot$ HAMSOM $\cdot$ RCP8.5

\section{Introduction}

The South Brazil Bight (SBB) is located between Cabo Frio and the Santa Marta Cape ( $23^{\circ}$ to $28.5^{\circ} \mathrm{S}$, Fig. 1) (Castro and Miranda 1998). Its most striking characteristic is an abrupt change in coastline orientation, from NE-SW to E-W in the Cabo Frio region. This is accompanied by a progressively larger continental shelf, extending over $200 \mathrm{~km}$ at its central portion before reducing back to approximately $70 \mathrm{~km}$ at the Santa Marta Cape (Piola et al. 2018). Campos et al. (1995) conducted one of the first studies regarding the

Mihael Machado de Souza

mihael.de.souza@uni-hamburg.de

1 Institut für Meereskunde, Universität Hamburg, Hamburg, Germany

2 Helmholtz-Zentrum Geesthacht, Geesthacht, Germany

3 Centro de Estudos do Mar-UFPR, Pontal do Paraná, Brazil thermodynamic state and circulation in the SBB, based on an array of CTD measurements and geostrophic calculations. Based on their analysis, the SBB water mass is mainly composed of Tropical Water (TW: $>20^{\circ} \mathrm{C}$ and salinity $>36.4$ ), South Atlantic Central Water (SACW: $<20^{\circ} \mathrm{C}$ and salinity $<36.4)$ and Coastal Water $(\mathrm{CW})$. The latter is a result of the dilution of ocean water by the local freshwater discharge from several estuarine systems in this region. It is also affected by the intrusion of colder and fresher water associated with the Plata River (Campos et al. 1996), with its plume having been identified up to $24^{\circ} \mathrm{S}$ (Piola et al. 2005 ) within the SBB. This intrusion happens mostly during winter and is driven by southwesterly wind anomalies associated with cold fronts (Piola et al. 2005; Pimenta et al. 2005), and to a lesser extent to very high discharge periods during El Niño events (Campos et al. 1999).

At the shelf-ocean interface, the SBB dynamics is dominated by the Brazil Current (BC) (Campos et al. 1995, 2000; Silveira et al. 2000). The predominantly southwestward flow 


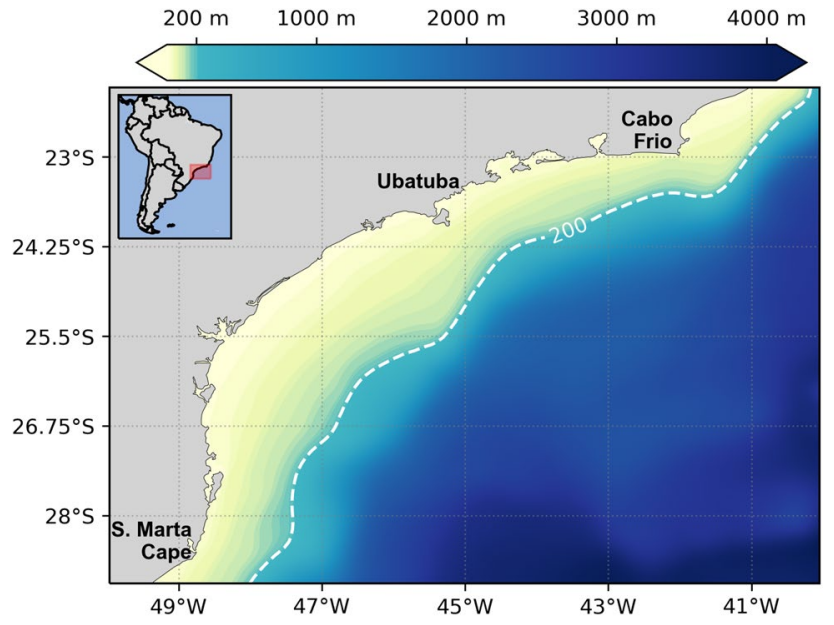

Fig. 1 Location of the South Brazil Bight, showing its bathymetry. The white dashed line marks the shelf break (200 $\mathrm{m}$ isobath)

associated with the BC is composed of TW in the upper 200 $\mathrm{m}$ of the water column, followed by SACW until $750 \mathrm{~m}$ and Antarctic Intermediate Water (AAIW) down to $900 \mathrm{~m}$ (Campos et al. 1995). Of note is that the sudden change in coastline orientation creates intense meso-scale activity along the main $\mathrm{BC}$ flow, with a general conversion of eddy- to mean-kinetic energy (Oliveira et al. 2009). This meso-scale activity has been suggested to induce shelf break upwelling in the region, through the development of cyclonic meanders that propagates southward from Cabo Frio (Campos et al. 2000; Castelao et al. 2004; Castro et al. 2006). These meanders would be formed due to barotropic shear instabilities associated with topographic Rossby waves (Silveira et al. 2000) developed along the BC. Palma and Matano (2009), however, suggested that this shelf break upwelling is rather a consequence of coastal geometry. They argued that changes in bottom topography would modify the meridional pressure gradient along the $\mathrm{BC}$ pathway and induce inshore flow in the bottom boundary layer. This process would be independent of the meso-scale activity and account for the differences in the effectiveness of the SACW upwelling in the northern and southern portions of the SBB.

Aside from the upwelling of SACW related to the BC dynamics, the SBB is characterized by the presence of a second upwelling regime that affects the region year-round (Campos et al. 2000; Palma and Matano 2009). This second regime is controlled by the wind-driven Ekman transport. In this region, wind-driven upwelling is favorable throughout the year due to persistent northeasterly winds associated with the South Atlantic Subtropical High (Castro and Miranda 1998; Lima et al. 1996; Castelao et al. 2004). This process is most effective during austral summer, when Cerda and Castro (2014) found SACW volumes on the shelf twice as large as for the TW and Campos et al. (2000) found the
SACW signal as close as $50 \mathrm{~km}$ to the coastline, retreating closer to the shelf break (depths $>100 \mathrm{~m}$ ) during winter. These seasonal differences are mainly a consequence of the passage of cold atmospheric fronts during winter, bringing strong southerly winds to the region (Castro and Miranda 1998). Möller et al. (2008) also demonstrated how this seasonal wind variability controlled the water mass distribution along the Southern Brazilian shelf, south of the SBB, being responsible for the SACW upwelling at the Santa Marta Cape.

The SBB also has large economic importance for Brazil. It is the location of some of the largest crude oil deposits (Santos Bay) available for exploration, and very productive fisheries grounds that fuel local and international markets (Castro et al. 2006). On an ecological sense, Brandini et al. (2014) demonstrated how the SACW intrusion improved light conditions for phytoplankton growth and provided missing nutrients (especially nitrate), fueling primary production at the base of the euphotic zone. They also proposed that the periodical intrusion and regression of SACW due to the wind-driven Ekman transport was used throughout the diatoms life cycle to maintain a presence within this nutrient-rich environment, contributing to the formation of a deep chlorophyll maximum at the SACW/(TW, CW) interface. However, anthropogenic climate change has been shown to impact the ecological state of affected regions due to the ecosystem's response to abiotic changes (e.g. temperature and sea level rise) and to emergent ecological responses (e.g. zonation patterns and biogeographical ranges) (Harley et al. 2006). Recently, Brandini et al. (2018) stressed how understanding climate change's impacts on the SBB is crucial for better management of its coastal tourism and aquaculture.

Notwithstanding, no long-term studies are available in this region about the impacts of a changing climate under increasing atmospheric greenhouse gas (GHG) concentrations. Analysis of current observational data as well as future projections based on global Earth system models predict an overall expansion of the Hadley circulation (Davis and Rosenlof 2012; Hu et al. 2018) and a southward migration of the sub-polar jets (Barnes and Polvani 2013), with an accompanying southward migration of the Southern Hemisphere atmospheric circulation (Kushner et al. 2000; Rykaczewski et al. 2015). Under these conditions, a larger portion of the SBB could be under the influence of the stronger NE winds that favors upwelling conditions year-round. These could lead to an increase in the upwelling's strength and/or persistence. Similar effects have been found across different locations, both on the global (Sydeman et al. 2014; Wang et al. 2015) and regional (Snyder et al. 2003; Miranda et al. 2013; Praveen et al. 2016; Sousa et al. 2017) scales. More recently, Varela et al. (2018) identified cooling trends north of the SBB when compared to the adjacent open ocean, based on a global analysis of AVHRR data from 1982 to 
2015. They linked this SST decrease to a reinforcement of upwelling favorable winds but did not investigate further potential changes in the course of future scenarios. Nevertheless, despite the usefulness of global climate models in providing a general picture of the expected impacts of increased GHG concentrations, their ability to properly represent regional processes is limited due to their coarse resolution (Wang et al. 2010; Snyder et al. 2003). This can lead to biased responses on the regional scale due to the underrepresented local processes (Praveen et al. 2016).

In the present study, we conduct an investigation of potential climate impacts on the two upwelling regimes in the SBB that takes into account meso-scale processes in the ocean circulation. This is carried out by downscaling results from a global Earth system model (MPI-ESM-MR, Giorgetta et al. 2013) using a regional ocean model (HAMSOM) of higher grid resolution, under a strong warming scenario (RCP8.5-IPCC 2014). This approach allows for an estimation of the upper-bound effects associated with anthropogenic climate change and the influence of this external forcing to the SBB, as well as to the mechanisms governing both upwelling regimes.

\section{Methods}

In this study, we utilize the outputs of a large-scale Earth system model (MPI-ESM-MR, Max-Planck Earth System Model-Mixed Resolution (Giorgetta et al. 2013)) in the context of the Coupled Model Intercomparison Project Phase 5 (CMIP5) to provide boundary conditions (atmosphere and ocean) for a high-resolution domain $\left(1 / 12^{\circ}\right)$ spanning the whole South Atlantic $\left(10^{\circ} \mathrm{N}\right.$ and $54^{\circ} \mathrm{S}$ and $69^{\circ} \mathrm{W}$ and $19^{\circ}$ $\mathrm{E}$, approximately). The high-resolution simulations have been performed using the HAMSOM model (HAMburg Shelf Ocean Model Backhaus 1985; Pohlmann 1996, 2006) and focus on properly resolving the upper ocean flow with a crude resolution of the deep ocean circulation. All forcing data has been bias-corrected using a combination of AVISO satellite information, 3D temperature and salinity profiles from SODA (Carton and Giese 2008) and atmospheric data from the NCEP/NCAR reanalysis dataset (Kalnay et al. 1996). For a detailed description of the model configuration and setup and the model evaluation see de Souza et al. (2019).

Our total simulation period ranges from 1950 to 2100 with the interval between 1950 and 1974 reserved to spinup the model, necessary due to the bias-correction and the increased horizontal resolution compared to the global model. The remaining 125 years are then separated into a historic (35 years, from 1975 to 2009) and prognostic periods (90 years, from 2010 to 2100). In order to characterize the impacts of climate change as an upper-bound effect in the SBB, we utilize MPI-ESM model results reflecting the representative concentration pathway 8.5 (RCP8.5, defined from 2005 onward) combined with the historical run (Hist, defined until 2004), and contrasting against pre-industrial GHG levels (Control) (IPCC 2014). For the combined Hist/ RCP8.5 simulations, five ensemble members have been produced. These ensemble members reflect random modifications (within $1 \%$ of their base values) to the initial temperature and salinity fields of our high-resolution simulations and account for the regional model's internal variability.

HAMSOM's results are saved as daily averages throughout the whole simulation and consist of data on sea surface heights, temperature, salinity and zonal and meridional current velocities. Seasonal patterns are analyzed by comparing austral summer (December, January and February - DJF) and winter (June, July and August-JJA) climatologies, derived from monthly-averaged data. Because we are also interested in the long-term effects associated with anthropogenic climate change, all seasonal variability is then removed by applying a 12-months running mean, yielding the inter-annual signal.

Our analysis focuses on the SBB region (Fig. 1), limited offshore by the continental shelf break (depths $<200 \mathrm{~m}$ ). Long-term climate effects are estimated by comparing time slices representing the end of century (EofC: 2071-2100) and the historical (Hist: 1980-2009) climatologies. These projected change signals are then compared with the variance of the Control simulation to assess statistical significance. To derive a robust and representative variance of the Control scenario, we calculate all possible 30-year climatologies, starting from 1980 until 2071. The standard-deviation from these climatologies is then multiplied by $\sqrt{2}$ to double the variance and increase confidence in the calculated changes, and by 1.96 to ascribe a significance level of $95 \%$. When the projected change signal is stronger than this boosted Control variance, we can consider the found differences statistically significant, while accounting for the possibility of model drift within the simulations. This process follows the methodology described by Mathis et al. (2018).

Traditionally, the intrusion of SACW in the SBB is estimated based on vertical temperature profiles and isotherm depth $\left(17^{\circ} \mathrm{C}\right.$ to $20^{\circ} \mathrm{C}$, Campos et al. 1995 ; Castelao et al. 2004; Brandini et al. 2014; Castro 2014; Cerda and Castro 2014), with modeling studies complementing these with bottom velocities (Palma and Matano 2009) or vertical velocities at specified depths (Campos et al. 2000). Unfortunately, changes in temperature and salinity due to increased GHG emissions are expected to have a measurable effect in the upper $700 \mathrm{~m}$ of the Earth's ocean (IPCC 2013), which would make separating changes in the isotherm position from the increased warming complicated in the depth range of the continental shelf $(\approx 200 \mathrm{~m})$. To evaluate this possibility in the SBB, we extracted all temperature and salinity data 
along the shelf break (white dashed line in Fig. 1) for the Control and Hist/RCP8.5 scenarios and plotted them in a T-S diagram for the historical and end of century climatologies (Fig. 2). Based on this diagram, we can see that no significant modifications on the water masses distribution is found during the Control simulation and the centroid of each climatology overlaps (white $X$ in Fig. 2). At the same time, there is a clear shift in both properties for the Hist/ RCP8.5 scenario, affecting the whole water column. Based on these results, estimating the SACW's change signal over the SBB based on water mass characteristics would lead to uncertainties due to the general temperature and salinity increases expected under a warming climate.

As an alternative, changes to the SACW upwelling are estimated based on the vertical velocity at the bottom of the mixed-layer $\left(\mathrm{W}_{\mathrm{MLD}}\right)$. The bottom-parallel flow associated with the upwelling at the shelf break is proportional to the vertical velocity over the shelf, while the upwelling associated with the meso-scale regime directly over the shelf break would have a clear vertical influence that should also be captured at the mixed-layer. This way, we can represent both upwelling regimes described in the literature for the SBB using a single reference property. The mixed-layer depth (MLD) was calculated based on the temperature difference criteria, using a threshold of $-0.5^{\circ} \mathrm{C}$ when compared to the sea surface temperature (SST), as first proposed by Levitus (1983). This ensures that the calculated $\mathrm{W}_{\text {MLD }}$ is physically consistent throughout the simulation period, always representing changes in the vertical transport at the top of the thermocline. In case the calculated MLD is deeper than the total depth at the cell (possible close to the shoreline), all interpolated values at those cells are set as undefined for that time step and not considered in further calculations.

\section{Results}

\subsection{Ensemble evaluation}

To verify the quality of our ensemble simulations and evaluate the impact of the system's internal variability on the model results, we calculate the domain-averaged (area of Fig. 1) SST, MLD and the upwelling velocities at the bottom of the mixed-layer $\left(\mathrm{W}_{\mathrm{Upw}}\right)$ for all five ensemble members as well as for the median of all ensembles. In this case, the median was chosen in order to ensure that the generated dataset is comprised of information found in at least one of the ensemble members.

For all evaluated variables, the median preserved the dominating frequency range of the time series (Fig. 3). Among these properties, the highest ensemble spread is found for $\mathrm{W}_{\mathrm{Upw}}$. This is attributed to slight differences in the spatial upwelling spread over the seasonal scale within ensemble members. Nevertheless, there is a $0.92 \pm 0.01$ correlation between each individual simulation and the median. Based on these results, uncertainties associated with the internal variability within our simulations can be disregarded, and the calculated median based on the ensemble members can be used as a representative case for the Hist/RCP8.5 scenario. This reflects the strong influence of the external forcing global model on the ensemble spread, which has also been shown for coupled oceanatmosphere downscalings for the Northwest European shelf (Mathis et al. 2018).
Fig. $2 \mathrm{~T}-\mathrm{S}$ diagram of samples extracted along the SBB's shelf break for the Control and Hist/RCP8.5 scenarios. Samples related to the historical climatology (1980-2009) are represented by triangles, whereas samples related to the end of century climatology (2071-2100) are represented by squares. The color scheme represents the depth at which each data was extracted. The white cross is the centroid of each point distribution, for each evaluated period. Green, yellow and blue backgrounds portray the temperature and salinity boundaries for the Coastal Water, Tropical Water and South Atlantic Central Water, respectively

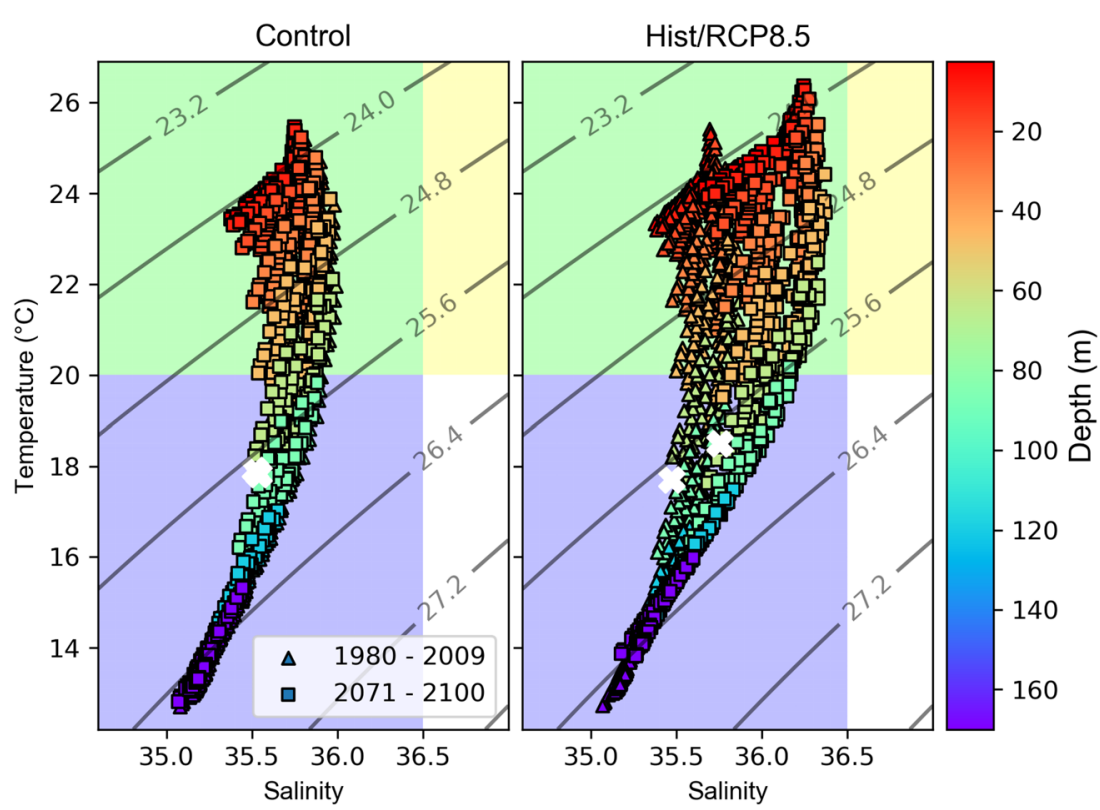




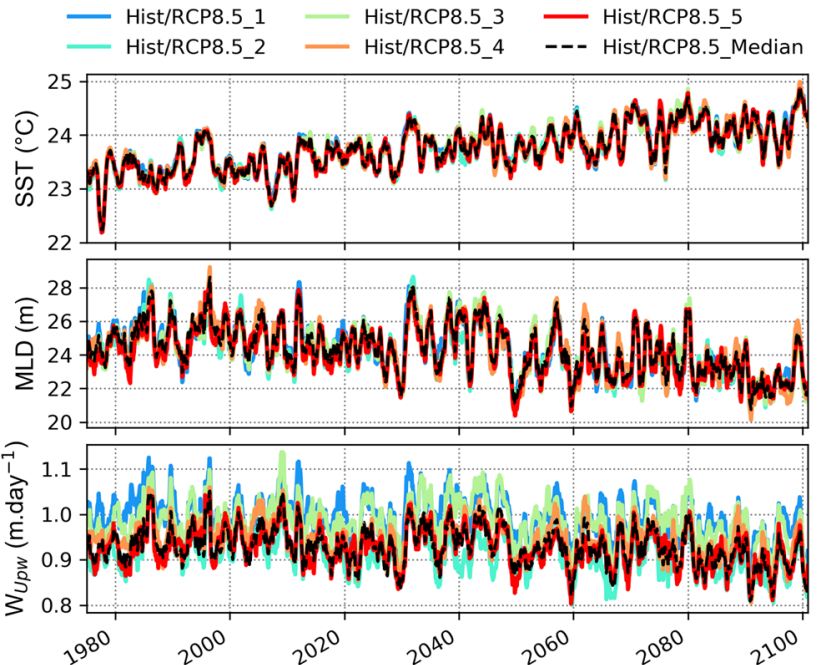

Fig. 3 Domain-averaged sea surface temperature (SST), mixed-layer depth (MLD) and upwelling velocity at the bottom of the mixed-layer $\left(\mathrm{W}_{\mathrm{Upw}}\right)$. Colored solid lines represent the different ensemble members, whereas the black dashed line represents the median. The chosen domain is depicted in Fig. 1

\subsection{Climatic impacts in the SBB}

As expected, a clear seasonal signal of the upwelling was found across the SBB under present-day climatic conditions (Fig. 4, left panels). This, however, is restricted to the middle and inner shelf regions. During austral summer, upwelling dominates the bottom of the mixed-layer in the central and southern parts of the SBB, with the process being interrupted during winter by the advances of cold atmospheric fronts from the south. The higher upwelling than downwelling rates lead to a dominant upwelling pattern in the inter-annual scale, stronger around the Santa Marta cape (refer to Fig. 1 for the location). In contrast, a dipole structure can be seen along the shelf break and the northern sector (i.e., the Cabo Frio region). This dipole structure seems to have a strong correlation with the bottom topography at the shelf break, with downwelling cores followed by upwelling cores as the $\mathrm{BC}$ flows south along the ridges. This structure shows a weak seasonality and, essentially, acts as a shelf boundary to the general upwelling found during summer for most of the SBB. At Cabo Frio, specifically, this upwelling extends throughout the whole shelf, leading to stronger upward flow when compared with the remaining of the SBB coastline. These results reflect the coexistence of two different upwelling regimes on the inner shelf and along the shelf break of the SBB (Campos et al. 2000).

Anthropogenic climate change impact on the upwelling is assessed through the calculation of the change signal (Fig. 4, right panels). We find a statistically significant decrease of the upwelling strength along the shelf break during all periods, showing a weakening of the dipole structure-i.e.,

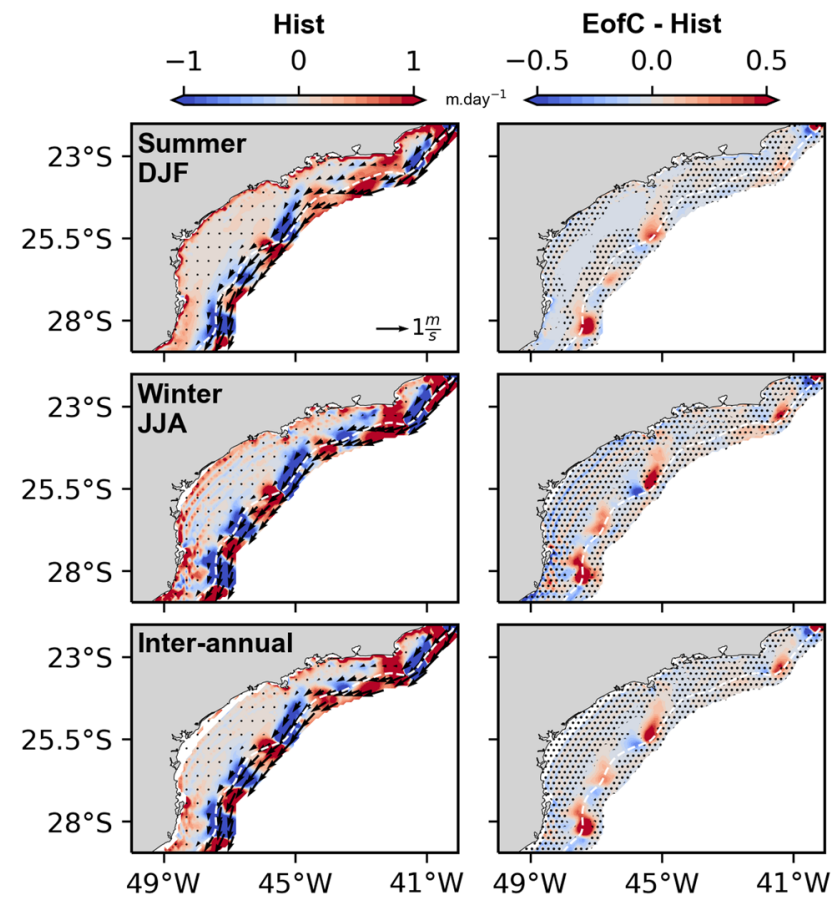

Fig. 4 Historical climatology of the vertical velocity at the bottom of the mixed-layer ( $\mathrm{W}_{\mathrm{MLD}}-1980-2009$, left panels) for austral summer, winter and inter-annual scales and their respective projected change signals (EofC-Hist, right panels). Positive values for the climatologies indicate upward flow. Data is shown up to the $1000 \mathrm{~m}$ isobath, and the dashed white line identifies the $200 \mathrm{~m}$ isobath and marks the shelf break. Hashed regions in the projected change signals indicate where the difference is smaller than the control variability and therefore statistically not significant, and colors need to be interpreted in relation to the direction of the climatological flow. Arrows in the left panels represent the horizontal velocity field at the bottom of the mixed-layer. All values for the $\mathrm{W}_{\mathrm{MLD}}$ are in meters per day

positive values of the change signal are associated with downwelling cores and vice-versa. During austral summer, however, a reduction of the upwelling strength is also verified on the middle and inner shelf of the central and southern SBB sectors. The northeastern sector (around Cabo Frio) shows the weakest changes among the evaluated periods.

These strong upward vertical flows at the Cabo Frio region lead to a marked lower SST, in particular during summer, that is also persistent on the inter-annual scale (Fig. 5, left panels). In this region, SST is up to $4{ }^{\circ} \mathrm{C}$ lower than at the central sector. This is also apparent at the Santa Marta cape, although to a lesser geographical extent. Nevertheless, lower temperatures are found across the whole SBB when compared with the warmer waters transported by the $\mathrm{BC}$, reflecting the overall effectiveness of the SACW upwelling in cooling surface waters. On the inter-annual scale, we found the SST across the SBB to vary spatially by up to $1.8^{\circ} \mathrm{C}$ and exceeding $2^{\circ} \mathrm{C}$ during summer along the shoreline. These spatial differences are not as strong during winter, although we can still see slightly colder waters in the 


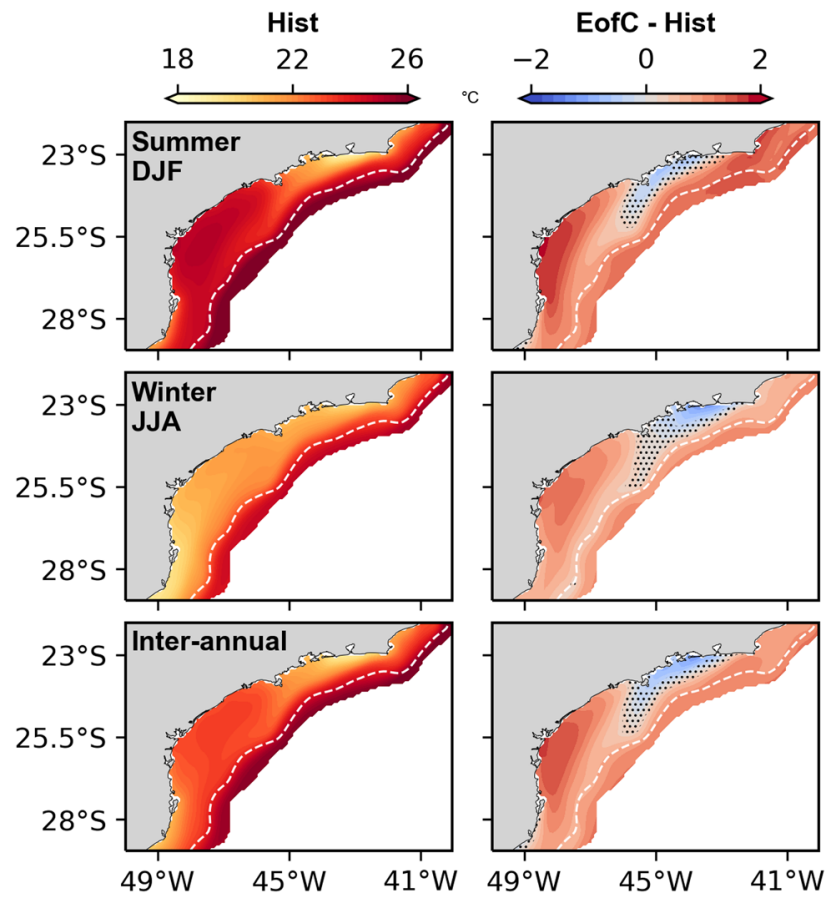

Fig. 5 Historical climatology of sea surface temperature (SST1980-2009, left panels) for austral summer, winter and inter-annual scales and their respective projected change signals (EofC-Hist, right panels). Data is shown up to the $1000 \mathrm{~m}$ isobath, and the dashed white line identifies the $200 \mathrm{~m}$ isobath and marks the shelf break. Hashed regions in the projected change signals indicate where the difference is smaller than the control variability and therefore not statistically significant. All values are in degree Celsius

narrower shelf regions. The change signal at the end of the 21 st century also reflects these regional differences (Fig. 5, right panels). Although SST increases across most of the $\mathrm{SBB}$, there is a slight but statistically significant temperature decrease at the northern sector of about $1{ }^{\circ} \mathrm{C}$. This mainly extends between Cabo Frio and Ubatuba (see Fig. 1 for location references). The increase in temperature is also smaller along the shelf break, being influenced by the shelf break upwelling regime. In contrast, bottom temperature increases along the shelf break (up to $1.2^{\circ} \mathrm{C}$ ) but decreases across most of the middle and inner shelf regions (Fig. 6, right panels). The historical climatology (Fig. 6, left panels), in this case, can be considered a reflection of the SACW spread over the shelf, retreating offshore in winter when compared with the summer season. The projected bottom temperature increase is a reflection of the general warming found previously on the TS-diagram over the ocean-shelf edge (Fig. 2), whereas the decreasing temperatures over the shelf indicate a stronger influence of the SACW intruding closer to shore.

In contrast, changes to sea surface salinity (SSS) show a more homogeneous pattern when compared to the SST (Fig. 7). We found a statistically significant increase across the whole SBB with a maximum of 0.5 in winter close to

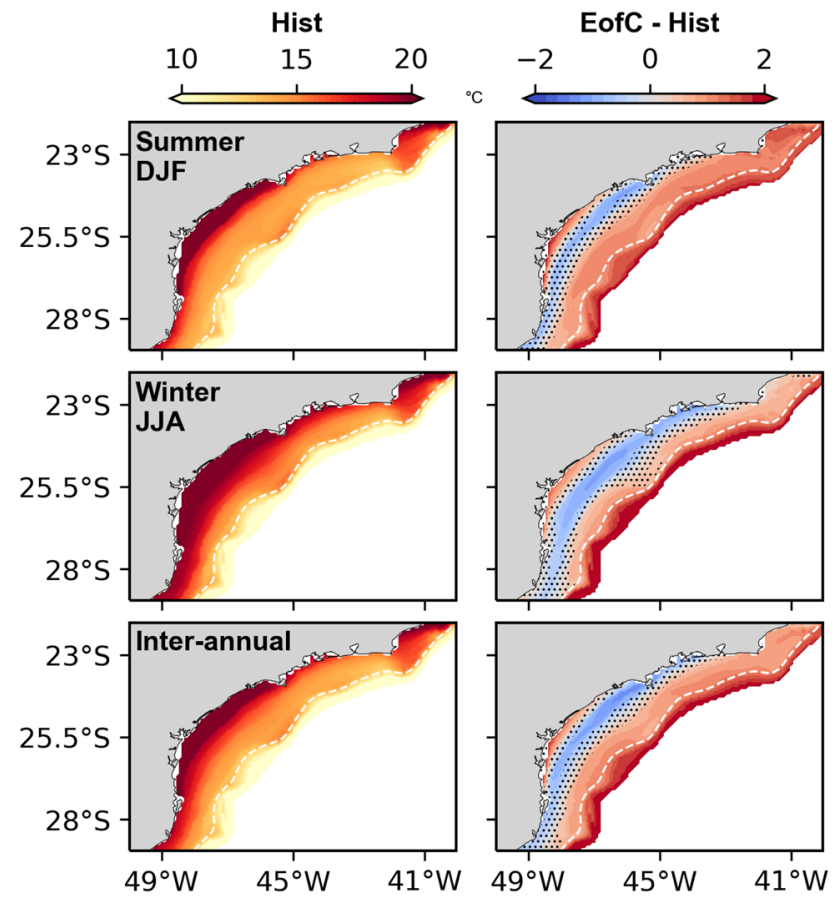

Fig. 6 Historical climatology of the shelf's bottom temperatures (1980-2009, left panels) for summer, winter and inter-annual scales and their respective projected change signals (EofC-Hist, right panels). Data is shown up to the $1000 \mathrm{~m}$ isobath, and the dashed white line identifies the $200 \mathrm{~m}$ isobath and marks the shelf break. Hashed regions in the projected change signals indicate where the difference is smaller than the control variability and therefore not statistically significant. All values are in degree Celsius

the shelf break, with differences between summer and winter smaller than 0.2. The distinction between the SSS increase over the continental slope and the shelf is also much more evident in winter than summer, in contrast to changes in SST. This, combined with the presence of a clear plume signal propagating from the southern sector, indicates the influence of the Plata River Plume discharge in the SBB and suggests its importance as a dynamical feature of this region.

\section{Discussion}

\subsection{The two upwelling regimes}

Our results also reflect the presence of two different upwelling regimes in the SBB (Fig. 4). The first regime dominates the inner and middle shelf regions in the central and southern SBB sectors and has a strong seasonality (Fig. 4, left panels). Physically, the process has been previously explained by Castro and Miranda (1998), where the prevalent NE summer winds induce offshore surface transport in the SBB, being disrupted during winter by southerly winds associated with the passage of cold fronts. This is 


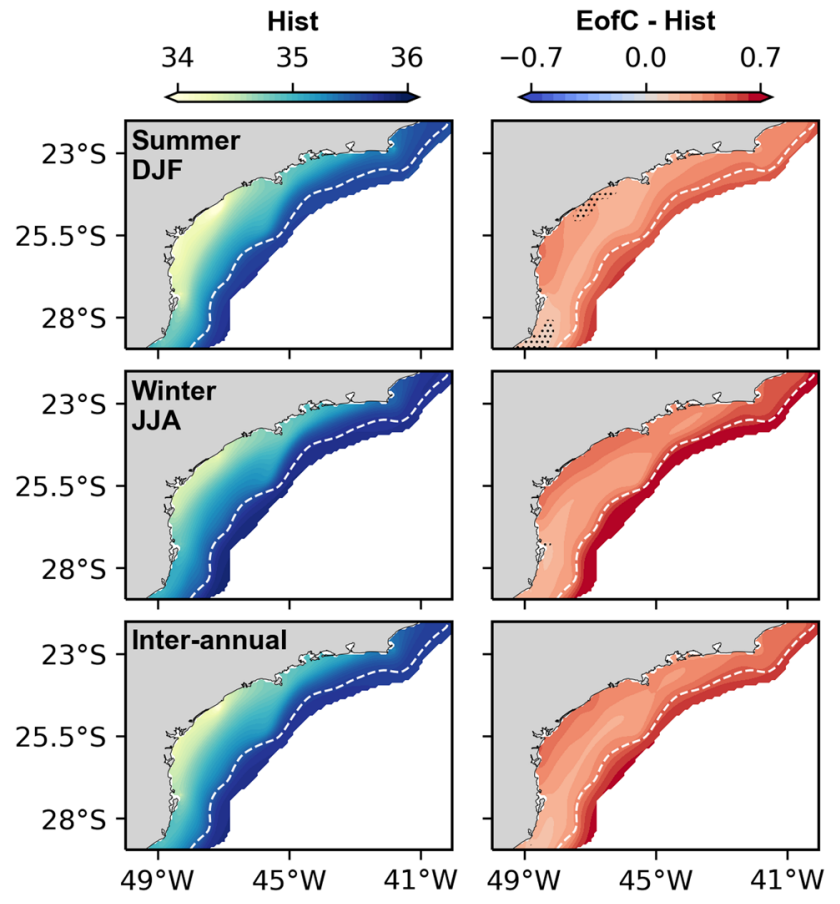

Fig. 7 Historical climatology of sea surface salinity (SSS-19802009, left panels) for austral summer, winter and inter-annual scales and their respective projected change signals (EofC-Hist, right panels). Data is shown up to the $1000 \mathrm{~m}$ isobath, and the dashed white line identifies the $200 \mathrm{~m}$ isobath and marks the shelf break. Hashed regions in the projected change signals indicate where the difference is smaller than the control variability and therefore not statistically significant

the classical Ekman upwelling, and essentially balances the offshore transport of surface TW and CW with the onshore transport of subsurface SACW (Castro and Miranda 1998; Lima et al. 1996; Castelao et al. 2004). The numerical experiments of Campos et al. (2000) and the recent works of Cerda and Castro (2014), Castro (2014) and Brandini et al. (2014) based on survey data showed how this upwelling regime has an impact across all stretches of the SBB on the seasonal scale, supporting the results found herein.

The second regime, in contrast, dominates the shelf break and the northern sector of the SBB and shows only a weak seasonality (Fig. 4, left panels). Campos et al. (1995) first proposed that the shelf break upwelling is driven by cyclonic meanders of the BC. Later, Campos et al. (2000) showed how this shelf break regime co-existed with the Ekman upwelling and was effective year-round, based on a combination of hydrographic data and model results. Meanwhile, Silveira et al. (2000) explained the formation of these cyclonic meanders based on the conservation of potential vorticity (II). According to these authors, as the $\mathrm{BC}$ overshoots the region around Cabo Frio due to the change in coastal geometry, it veers westward to conserve $\Pi$. This generates barotropic shear instability and leads to the creation of a topographical Rossby wave that propagates southwestward. This wave then generates the cyclonic meanders described by Campos et al. (2000), which produce upwelling at their leading edge and downwelling at their trailing edge. More recently, Palma and Matano (2009) did a comprehensive modeling study of the SBB and also identified a dominating role of the $\mathrm{BC}$ to the shelf break regime. However, they argued that it is rather its interaction with the bottom topography along the $\mathrm{BC}$ path that creates changes of the alongshore pressure gradient and drives the upwelling through the bottom boundary layer. Their proposed mechanism is similar to the one found by Oke and Middleton (2000) for the eastern Australian shelf.

Given both these explanations and based on our own results, we suggest that the mechanism is a combination of characteristics from both conceptual models. The experiments of Song and Chao (2004) provide the basis for our proposed explanation. They conducted an idealized study on the interaction of a varying bottom topography with a strong boundary current, similar to the conditions found in the SBB, in which a series of ridges can be seen along the $200 \mathrm{~m}$ isobath starting around Cabo Frio (see Fig. 1). Their results show that as the boundary current flows along the ridge topography, it creates a dipole structure attached to the ridge. This structure consists of a downwelling core upstream and an upwelling core downstream of the ridge. They also related the development of these dipole structures to changes in the relative vorticity $(\zeta)$, producing anticyclonic and cyclonic circulations over the downwelling and upwelling cores as the boundary flow meanders around these bathymetrical features. As a result, these dipoles were fixed in space, as identified in our results as well (Fig. 4).

In essence, this would corroborate the basis of Silveira et al. (2000) argument that the potential vorticity drives the shelf break upwelling regime, but not because of the generation of a topographical Rossby wave associated with the $\mathrm{BC}$ overshooting the latitude of Cabo Frio. The BC is under geostrophic balance and, as such, has to conserve $\Pi$ $\left(\Pi=\frac{(\zeta+f)}{D}\right)$ as it flows around a varying topography (Fig. 7, bottom right). Since its planetary vorticity (Coriolis parameter, $\mathrm{f}$ ) is always decreasing along its path, local changes in depth (D) have to be mostly balanced by changes in $\zeta$ (Fig. 8, top panels). This means that it gains positive $\zeta$ and spins anticyclonically as it travels upslope, generating a downwelling region. And the opposite is also valid, it gains negative $\zeta$ as it travels downslope, spinning cyclonically and generating upwelling. These changes in $\zeta$ also account for the meandering of the BC, as observed by Campos et al. (1995, 2000) and Castelao et al. (2004). A similar explanation for topographically induced upwelling has been proposed for the Vietnamese coast (Hein et al. 2013) and the Hainan coast at the South China Sea (Su and Pohlmann 2009). Nevertheless, for our argument to hold, we first have to establish that 
Fig. 8 Components of the potential vorticity conservation in the South Brazil Bight calculated at the bottom of the mixed-layer for the inter-annual variability case during the historical period (1980-2009). Top figures are the relative vorticity $(\zeta$, left $)$ and its tendency $\left(\zeta_{X Y}\right.$, right) and at the bottom are the absolute vorticity $(\zeta+f$, left) and the potential vorticity $(\Pi$, right). Streamlines over $\Pi$ represent the flow, with the varying thickness as an indication of relative flow strength. Data is shown up to the $1000 \mathrm{~m}$ isobath, and the dashed white line identifies the $200 \mathrm{~m}$ isobath and marks the shelf break
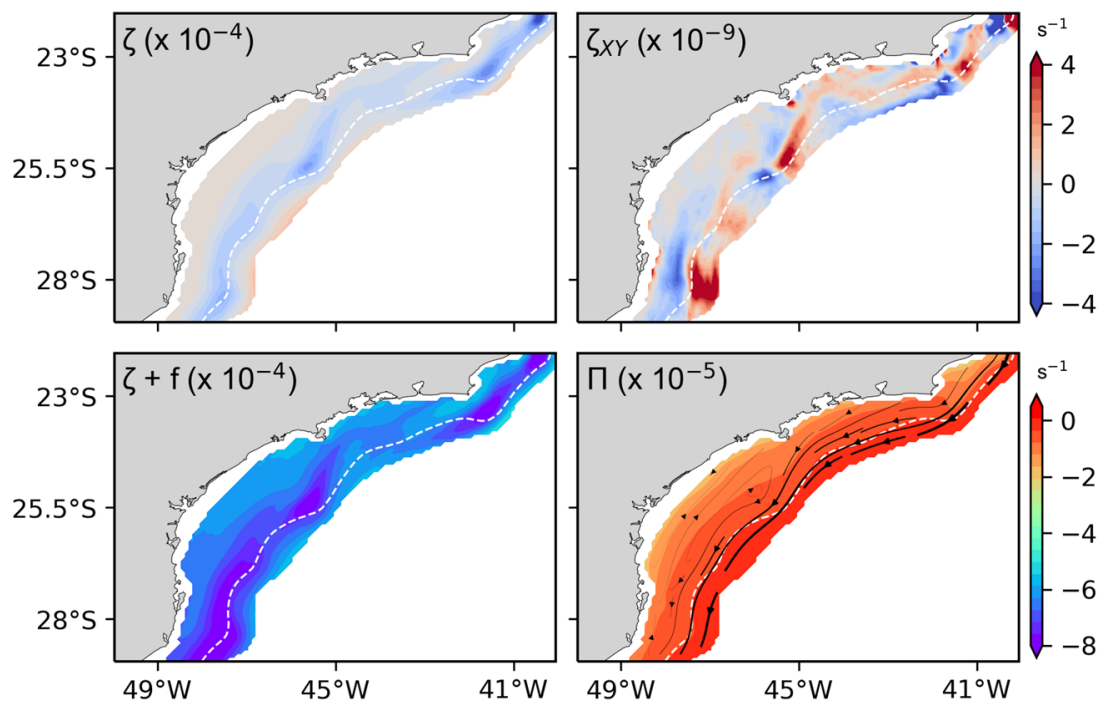

these ridges are indeed a feature of the local shelf break topography and that they are necessary to produce the shelf break upwelling.

To the first point, figure 4 of Campos et al. (2000) shows the $200 \mathrm{~m}$ isobath south of Ubatuba (for locations, see Fig. 1). In it, the presence of a ridge is clearly seen, similar to the profile found here. Not only that, but the presence of an upwelling core is seen downstream of this ridge, with no SACW signal upstream of it in any of their three cruises. The dipole structures found in our study can also be seen in their model results from their figure 7, where they show the cross-isopycnal velocity, although the shelf break profile was not superimposed in this image. The same ridge can also be seen in figure 13c) of Silveira et al. (2000), along with the ridges southeast of Cabo Frio and east of the S. Marta Cape (Fig. 1). Based on these results, we are confident in the presence of these ridges as actual topographical features along the SBB and their impact on the upwelling dynamics.

As for whether these features are necessary to produce the shelf break upwelling, it is interesting to compare our results to the ones from Palma and Matano (2009). Looking at their bathymetrical profile along the SBB (their figure 1), we can see that the $200 \mathrm{~m}$ isobath is very smooth and presents no features, although the change in coastal geometry around Cabo Frio is preserved. This means that, according to the argument from Silveira et al. (2000), the BC overshooting Cabo Frio should still produce the topographical Rossby wave that creates the cyclonic meanders. However, Palma and Matano (2009) results shown in their Figure 3 do not indicate any meandering of the $\mathrm{BC}$ flow. As a consequence, their upwelling signal is restricted to the northern sector around Cabo Frio, which is then transported southward by the surface flow over the shelf. This suggests that the shelf break upwelling regime is indeed dependent upon the topographical features. Unfortunately, they did not show results for the vertical velocities directly, so we have to limit our comparison qualitatively to the surface behavior of the BC.

Finally, as for the stronger upwelling signal found in the northern sector (Figs. 4, 5), the local reduction of the shelf width in front of Cabo Frio advectively accelerates the inshore flow and pushes the upwelled water from the shelf break towards the coastline. This is a process identified by Oke and Middleton (2000) with regards to the East Australian Current and by Cerda and Castro (2014) and Palma and Matano (2009) based on hydrographic climatologies and simulations for the SBB, respectively. Furthermore, it is likely further enhanced by the barotropic instabilities identified by Silveira et al. (2000), as the increased eddy kinetic energy generated in this region (Oliveira et al. 2009) can feed these dipole structures. These processes could contribute to maintain a strong presence of the SACW year-round in the Cabo Frio region (Fig. 4), as opposed to the rest of the SBB where the shelf is wider.

\subsection{Anthropogenic climate impacts to the upwelling regimes}

Upwelling strength and duration is expected to increase in the Benguela Current System in the eastern South Atlantic under increased anthropogenic forcing (Wang et al. 2015). Change is mostly attributed to an increase of the alongshore winds over the subtropical South Atlantic (Sydeman et al. 2014). This increase, in turn, is associated with a southward migration of the South Atlantic Subtropical High (Rykaczewski et al. 2015) in response to the expected southward migration of the westerlies over the Southern Ocean (Swart and Fyfe 2012; Wilcox et al. 2012; Barnes and Polvani 2013) and the widening of the Hadley circulation (Kang and Lu 2012; Davis and Rosenlof 2012; Hu et al. 2018). 
To confirm this behavior within our simulations, we calculated the wind speed climatologies for the historical and end of the century periods (Fig. 9) over our South Atlantic domain. Although we see no significant changes in the wind speeds associated with the general circulation over the South Atlantic Subtropical High (SASH), there is a clear southward migration of its center of approximately $2^{\circ}$. This is accompanied by a slight increase in wind velocities along the South American coast, as reported by Sydeman et al. (2014), but it also exposes the SBB to the stronger E-NE winds associated with the upper branch of the SASH. With this in mind, we calculated the offshore Ekman transport $\left(\mathrm{E}_{\mathrm{k}}=\frac{\tau_{y}}{\rho_{w} f}\right)$ for the SBB based on the alongshore wind stress $\left(\tau_{y}\right)$, considering a $45^{\circ}$ coastline orientation (Fig. 10). We found an increase in the Ekman forcing across the SBB for all periods, albeit much stronger during winter than summer. The exception is in the northeastern sector, where a small reduction can be seen during summer. These results are in line with the global atmospheric trends mentioned above and can also explain the increased spread of SACW over the shelf's bottom indicated by the bottom temperatures (Fig. 6). They do not, however, account for the reduction in the $\mathrm{W}_{\mathrm{MLD}}$, specially considering that the northeastern sector showed the least amount of significant changes when compared to the rest of the SBB.

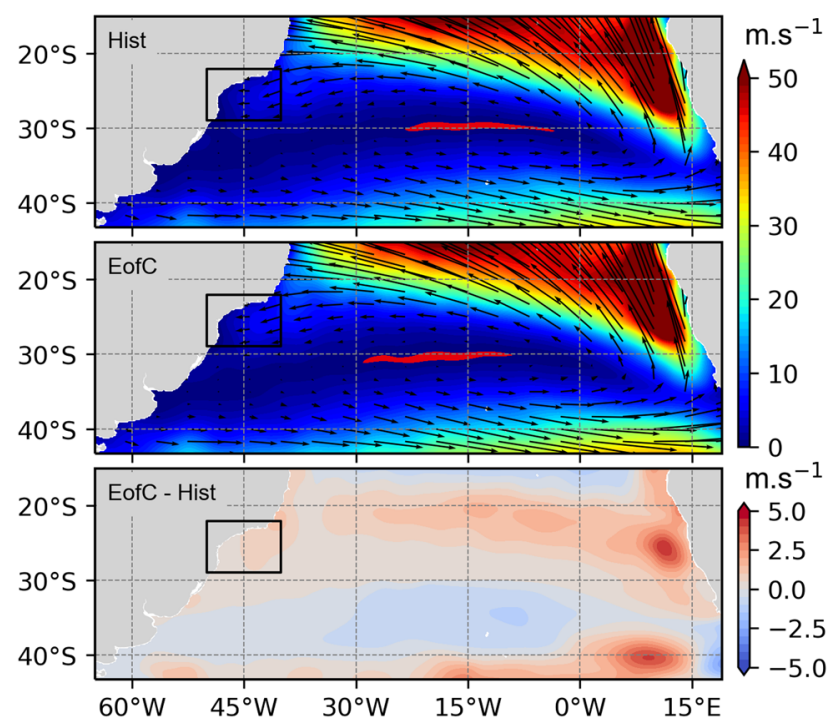

Fig. 9 Top and middle panels show the wind speed climatology for the historical (1980-2009) and end of the century (2071-2100) periods over the subtropical South Atlantic, respectively. Bottom panel highlights the change signal between both periods. The black box represents the South Brazil Bight domain analyzed in this study (Fig. 1). The red filled contour around $30^{\circ} \mathrm{S}$ in the upper two panels marks the center of the South Atlantic Subtropical High (wind speeds less than $0.3 \mathrm{~m} \mathrm{~s}^{-1}$ ). All values are in $\mathrm{m} . \mathrm{s}^{-1}$

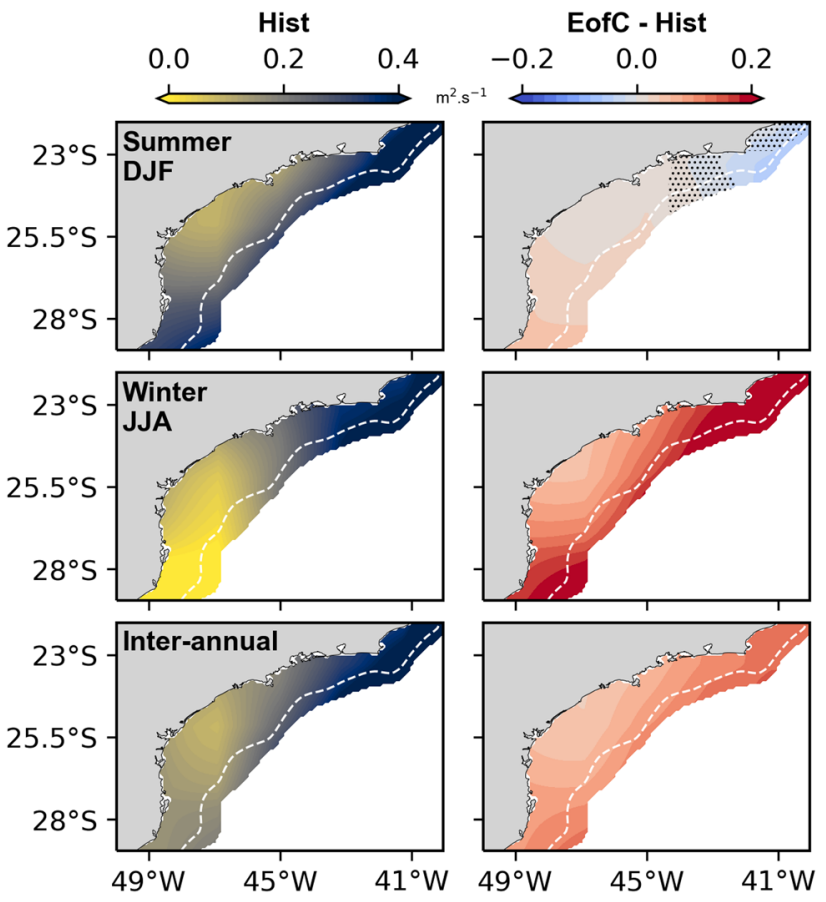

Fig. 10 Historical climatology of the offshore Ekman transport (1980-2009, left panels) of summer, winter and inter-annual scales and their respective projected change signals (EofC-Hist, right panels). Data is shown up to the $1000 \mathrm{~m}$ isobath, and the dashed white line identifies the $200 \mathrm{~m}$ isobath and marks the shelf break. Hashed regions in the projected change signals indicate where the difference is smaller than the control variability and therefore not statistically significant. All values are in $\mathrm{m}^{2} . \mathrm{s}^{-1}$

On a regional level, increased Ekman forcing leading to increased coastal upwelling is also expected in the Californian upwelling system (Snyder et al. 2003), the Iberian Peninsula (Miranda et al. 2013) and the Canary Upwelling Ecosystem (Sousa et al. 2017), based on the analysis of surface temperature fields. Notwithstanding, we found a reduction of the upwelling strength in the SBB in spite of these general atmospheric trends (Fig. 4, right panels). Along the Oman coast in the Indian Ocean, regional heterogeneities in the Ekman transport patterns led to divergent modifications in vertical transport (Praveen et al. 2016), accentuating the importance of local processes in defining variations in local upwelling. In the SBB, the intrusion of the Plata River Plume can be one of such relevant processes. Piola et al. (2005) and Pimenta et al. (2005) identified its northward intrusion up to $24^{\circ} \mathrm{S}$, which is congruent to the region of freshwater influence seen in the change signal in our results (Fig. 7). This plume brings fresher waters into the SBB, increasing the water column vertical stability. Its presence in the southern sector and along the middle shelf across all time scales also creates a clear cross-shelf salinity gradient and keeps the overall SSS increase below global projections for the southwestern South Atlantic (IPCC 2013). However, 
there is no predicted increase in the Plata River discharge for the RCP8.5, based on the MPI-ESM forcing utilized here, with a slight reduction of its volume input by approximately $100 \mathrm{~m}^{3} \mathrm{~s}^{-1}$ at the end of the $21 \mathrm{st}$ century. This reduction is not statistically significant when we consider that the standard-deviation for this discharge is above $1000 \mathrm{~m}^{3} \mathrm{~s}^{-1}$ and implies that this plume mainly acts as a buffer, reducing the general SSS increase in the SBB but does not contribute to the changes seen in upwelling strength.

Aside from increased alongshore winds and the changes to SSS, anthropogenic climate change is mostly visible on temperatures, primarily affecting the upper $700 \mathrm{~m}$ of the water column (IPCC 2013). This heat input affects the energy budget in the system, which can change the amount available to be converted from potential energy (PE) to kinetic energy (KE) and to induce motion. This is the concept of available potential energy (APE), first introduced by Lorenz (1955), and is considered a measure of the water column stability. We calculated the APE along the SBB as the change in PE between the actual state of water masses found within the model results and a reorganized stable water column (Fig. 11). This reorganization consists of rearranging vertical layers of the model, so that the highest densities are found at the bottom and the minimum PE state is achieved (i.e., the background potential energy). A more detailed description of this method can be found in Urakawa et al. (2013). We can see a decrease in APE across the inner and middle shelf regions at all temporal scales, indicating that the water column is becoming more stable under increased surface warming. For the winter and inter-annual scales, this means that the increase in the Ekman forcing is balanced by the higher stability and we see no significant changes to $\mathrm{W}_{\mathrm{MLD}}$ (Fig. 4, right middle and bottom panels). For the summer period, on the other hand, the smaller increase in $\mathrm{E}_{\mathrm{k}}$ is not enough to balance the increased stability and we see a weakening of $\mathrm{W}_{\text {MLD }}$.

Urakawa and Hasumi (2009) showed how Ekman upwelling/downwelling represents a conversion from KE to $\mathrm{PE}$, as the flow has to pull up/push down a heavier/lighter water parcel. This means that the change in water mass depth must come with gain/loss of PE, which is supplied by the conversion from KE. Under increased surface warming, the surface layer becomes lighter and requires more KE converted to PE to disturb the water column stability and pull-up the heavier water mass below. In our scenario, the KE input from the enhanced wind field is insufficient to overcome the stronger water column stability, decreasing the amount of water that is upwelled towards the mixedlayer. Since the surface layer is still under increased Ekman forcing, the additional transport of surface water has to be compensated across a larger portion of the shelf, which leads to the wider bottom intrusion of SACW seen through the bottom temperatures (Fig. 6). This could lead to an increase

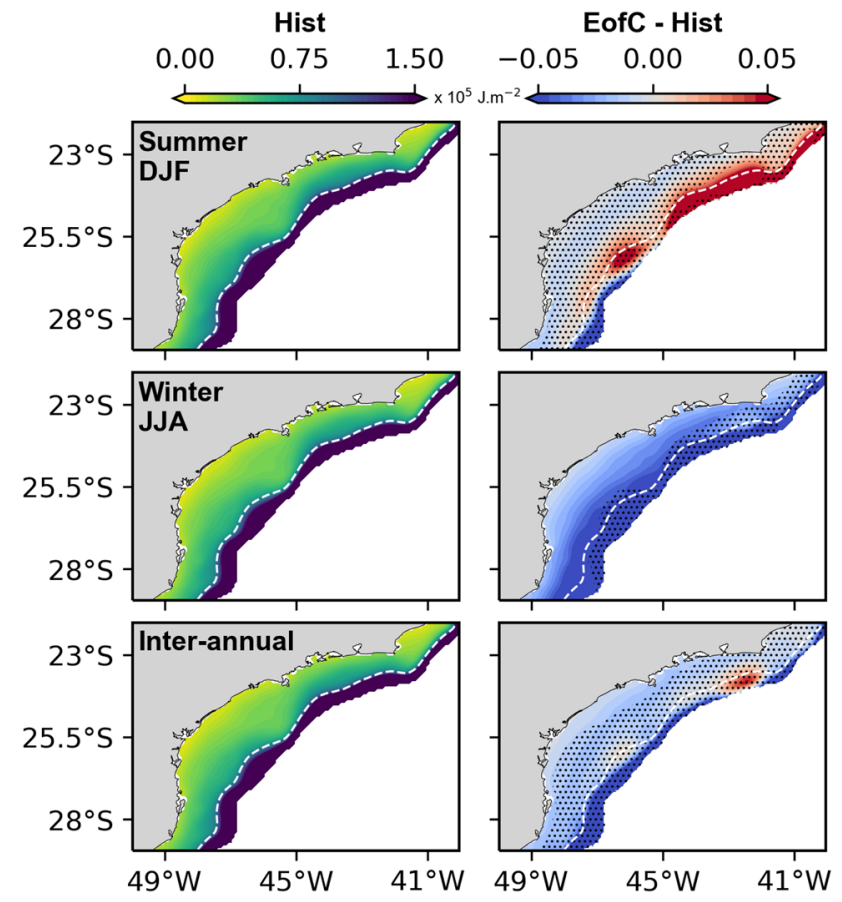

Fig. 11 Historical climatology of the available potential energy (1980-2009, left panels) for summer, winter and inter-annual scales and their respective projected change signals (EofC-Hist, right panels). Data is shown up to the $1000 \mathrm{~m}$ isobath, and the dashed white line identifies the $200 \mathrm{~m}$ isobath and marks the shelf break. Hashed regions in the projected change signals indicate where the difference is smaller than the control variability and therefore not statistically significant. All values are in $\mathrm{J}_{\mathrm{m}} \mathrm{m}^{-2}$

in nutrient availability at deeper layers and enhance the deep chlorophyll maximum identified by Brandini et al. (2014), but reduces the input of SACW to the mixed-layer. Since we have not involved a biogeochemistry or ecosystem model in our simulations, a more targeted study considering these impacts on nutrients dynamics over the shelf would be necessary to properly clarify these questions and its consequences to the shelf productivity.

Although the relation between increased Ekman forcing and water column stability explains the weakening of the Ekman upwelling, it does not satisfactorily address the weakening of the shelf break upwelling as well. This is because we still see a decrease in $\mathrm{W}_{\text {MLD }}$ in austral summer as well as winter, even though the APE change over the shelf break suggests a less stable water column during summer, particularly in the northern sector (Fig. 11). Both our results (see Sect. 4.1) and previous studies (Campos et al. 1995, 2000; Silveira et al. 2000; Palma and Matano 2009) identify a close relation between this upwelling regime and the $\mathrm{BC}$, so it behooves us to look at the $\mathrm{BC}$ dynamics over the 21 st century (Fig. 12). A decreasing trend south of $25^{\circ} \mathrm{S}$ can be clearly identified, which agrees spatially with the strongest decrease of the shelf break upwelling seen in our 

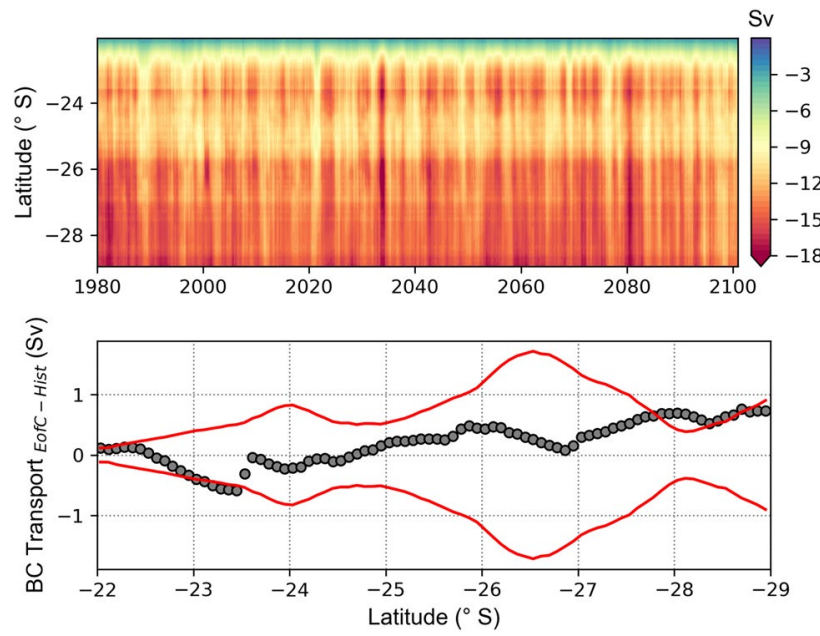

Fig. 12 At the top, Hovmöller diagram of the Brazil current transport (in Sverdrups) along the extension of the South Brazil Bight during the analyzed time period (1980-2100). At the bottom, differences between its climatological transport at the end of the century (EofC, 2071-2100) and the historical period (Hist, 1980-2009). The red solid line in the bottom graphic is the confidence interval calculated based on the control simulation. Samples within the red region are within our uncertainty range based on the control. Negative differences indicate a strengthening of the $\mathrm{BC}$ transport whereas positive values indicate weakening, since the Brazil current flows southward

results (Fig. 4). Not only that, but the slight increase in BC transport in the northern sector could explain why we found mostly no differences for this sector, or even a slight increase of the upwelling at the northern shelf break. However, these changes are mostly small and within our uncertainty range when considering our Control variability, which likely stems from the lack of a clear increase in the SASH wind circulation (Fig. 9). In this case, these trends found on the BC transport would reflect its adjustment to the new gyre position. It would also suggest that the shelf break regime is highly sensitive to changes in the $\mathrm{BC}$ transport. This would be a direct consequence to the dependence of the shelf break upwelling to changes in the relative vorticity, as increasing the $\mathrm{BC}$ would lead to increased flow divergence.

Finally, both upwelling regimes have a clear impact on surface warming (Fig. 5, right panels). In general, the maximum end of century SST increase over the shelf $\left(1.8^{\circ} \mathrm{C}\right.$, Fig. 4) is lower than the projected $2{ }^{\circ} \mathrm{C}$ to $3{ }^{\circ} \mathrm{C}$ increase over the SW South Atlantic for the RCP8.5 scenario (IPCC 2013). The consistent upwelling of colder SACW seems to dampen the impact of increasing radiative forcing, even under a strong climate scenario. Similar results were found by Miranda et al. (2013) in the Iberian Peninsula, by Praveen et al. (2016) along the Oman coast and by Sousa et al. (2017) in the Canary upwelling system. The smaller SST increases over the shelf break when compared to the middle shelf would also suggest that the $\mathrm{BC}$ upwelling is a stronger mechanism in dampening the surface warming. This is even more striking over the NE sector of the SBB, where we see a decrease in SST. Our results suggest that SST in this region is strongly influenced by the SACW upwelled at the adjacent shelf break and advected towards the coast. This is then spread SW by the surface circulation along the SBB, with this pathway having also been identified by Cerda and Castro (2014) on hydrographic data. Thus, the decrease in SST between Cabo Frio and Ubatuba could be a direct consequence of the increase in $\mathrm{BC}$ transport around $23^{\circ} \mathrm{S}$ (Fig. 12), with this water being transported back to the shelf break, south of Ubatuba. This would make the central SBB region more susceptible to global warming, since it would mainly be affected by the Ekman upwelling, which is less capable of compensating the increased warming, thus leading to higher SST increases in this region.

\section{Conclusions}

We presented further evidence of two distinct upwelling regimes in the SBB. The first is driven by the alongshore winds and represents the classical Ekman upwelling, whereas the second occurs mainly along the shelf break and is driven by relative vorticity, as the BC steers around the shelf edge. These two regimes would co-exist year-round and contribute to the overall upwelling of SACW in the $\mathrm{SBB}$, although the Ekman upwelling has a stronger seasonal component. For the northern sector of the Bight, however, the shelf break upwelling acts as a significant year-long source of SACW, affecting the shelf region up towards the coastline.

During the 21 st century, we found a general weakening of both upwelling regimes, although this behavior is in disagreement with what has been found in other systems worldwide. In our simulations, these reductions are mostly a response to increased water column stabilization due to the surface warming and a small reduction of the BC transport south of $25^{\circ}$ latitude. This evidences the importance of local processes in assessing the response of coastal environments to global climate change. Most upwelling studies rely on indexes derived either from temperature differences between the coastal and oceanic zones, or on the strength of the overlaying winds. As we demonstrated for the SBB, we still found a reduction of vertical velocities even under an increased offshore Ekman forcing, although we also found evidence of increased bottom spread of SACW over the shelf. In this light, we believe that an accurate assessment in localized upwelling regions has to consider a combination of local atmospheric forcings and ocean variables to take regional responses into account.

In the SBB, the combination of these two upwelling regimes dominates the SST response. SST increases over 
most of the shelf, but is lower than projections derived from Earth System Models under the RCP8.5 scenario. This is a direct response to the SACW upwelling that dampened the potential warming, up to the point of reducing surface temperatures over the northeastern sector when compared to present-day conditions. Over the middle and inner shelves in the central and southern sectors of the SBB, where the SACW signal was weaker, SST increases were similar to global projections of almost $2{ }^{\circ} \mathrm{C}$ under RCP8.5 conditions. As for the behavior at the northern sector, the SST decrease seems mostly driven by a slight strengthening of the $\mathrm{BC}$ at around $23^{\circ}$ latitude, which in turn is driven by an adjustment of the BC flow to a southward migration of the Subtropical High. This interaction highlights how sensitive the shelf break upwelling is to small variations of the $\mathrm{BC}$ transport and how important the $\mathrm{BC}$ response to anthropogenic climate change is to the upwelling in the SBB. Additional sensitivity studies focusing on isolating the effects promoted by the $\mathrm{BC}$ could shed further light into its response at the Cabo Frio region.

Acknowledgements Open Access funding provided by Projekt DEAL. Mihael M. de Souza would like to thank the Deutscher Akademischer Austauschdienst (DAAD) for the financial support (Research GrantDoctoral Programmes in Germany, 2016/17 (57214224)). Maurício A. Noernberg would like to thank CAPES (Coordenação de Aperfeiçoamento de Pessoal de Nível Superior) for the financial support (Project Number 88881.145867/2017-01). Supercomputing resources and data storage capacities have been provided by the Deutsches Klimarechenzentrum (DKRZ), Hamburg. We would also like to thank the two anonymous reviewers for their contributions to improving this manuscript.

Open Access This article is licensed under a Creative Commons Attribution 4.0 International License, which permits use, sharing, adaptation, distribution and reproduction in any medium or format, as long as you give appropriate credit to the original author(s) and the source, provide a link to the Creative Commons licence, and indicate if changes were made. The images or other third party material in this article are included in the article's Creative Commons licence, unless indicated otherwise in a credit line to the material. If material is not included in the article's Creative Commons licence and your intended use is not permitted by statutory regulation or exceeds the permitted use, you will need to obtain permission directly from the copyright holder. To view a copy of this licence, visit http://creativecommons.org/licenses/by/4.0/.

\section{References}

Backhaus JO (1985) A three-dimensional model for the simulation of shelf sea dynamics. Deutsche Hydrographische Zeitschrift 38:165-187

Barnes EA, Polvani L (2013) Response of the midlatitude jets, and of their variability, to increased greenhouse gases in the CMIP5 models. J Clim 26(18):7117-7135. https://doi.org/10.1175/JCLID-12-00536.1

Brandini FP, Nogueira M Jr, Simião M, Codina JCU, Noernberg MA (2014) Deep chlorophyll maximum and plankton community response to oceanic bottom intrusions on the continental shelf in the South Brazilian Bight. Cont Shelf Res 89:61-75. https://doi. org/10.1016/j.csr.2013.08.002

Brandini FP, Tura PM, Santos PP (2018) Ecosystem responses to biogeochemical fronts in the South Brazil Bight. Progress Oceanogr 164(December 2017):52-62. https://doi.org/10.1016/j.pocea n.2018.04.012

Campos EJD, Gonçalves JE, Ikeda Y (1995) Water mass characteristics and geostrophic circulation in the South Brazil Bight: summer of 1991. J Geophys Res 100(C9):18537-18550. https://doi. org/10.1029/95jc01724

Campos EJ, Lorenzzetti JA, Stevenson MR, Stech JL, De Souza RB (1996) Penetration of waters from the Brazil-Malvinas confluence region along the South American continental shelf up to $23^{\circ} \mathrm{S}$. Anais da Academia Brasileira de Ciencias 68(SUPPL. 1):57-58

Campos EJ, Lentini CA, Miller JL, Piola AR (1999) Interannual variability of the sea surface temperature in the South Brazil Bight. Geophys Res Lett 26(14):2061-2064. https://doi. org/10.1029/1999GL900297

Campos EJ, Velhote D, Da Silveira IC (2000) Shelf break upwelling driven by Brazil current cyclonic meanders. Geophysical Research Letters 27(6):751-754. https://doi.org/10.1029/1999GL010502

Carton JA, Giese BS (2008) a reanalysis of ocean climate using simple ocean data assimilation (SODA). Mon Weather Rev 136(8):2999_ 3017. https://doi.org/10.1175/2007MWR1978.1

Castelao RM, Campos EJD, Miller JL (2004) A Modelling Study of Coastal Upwelling Driven by Wind and Meanders of the Brazil Current. Journal of Coastal Research 203:662-671. https://doi. org/10.2112/1551-5036(2004)20[662:AMSOCU]2.0.CO;2

Castro BM, Brandini FP, Pires-Vanin AMS, Miranda LB (2006) Multidisciplinary oceanographic processes on the Western Atlantic continental shelf between $4^{\circ} \mathrm{N}$ and $34^{\circ} \mathrm{S}$. In: Robinson AR, Brink KH (eds) The Sea-the global coastal ocean: interdisciplinary regional studies and syntheses. Chap 8 , vol 14. Harvard University Press, Cambridge, pp 259-294

Castro BM, Miranda LB (1998) Physical oceanography of the Western Atlantic continental shelf located between $4^{\circ} \mathrm{N}$ and $34^{\circ} \mathrm{S}$. In: Robinson AR, Brink KH (eds) The Sea. Wiley, New York, pp 209-251

Castro BM (2014) Summer/winter stratification variability in the central part of the South Brazil Bight. Cont Shelf Res 89:15-23. https ://doi.org/10.1016/j.csr.2013.12.002

Cerda C, Castro BM (2014) Hydrographic climatology of South Brazil Bight shelf waters between Sao Sebastiao $\left(24^{\circ} \mathrm{S}\right)$ and Cabo Sao Tome $\left(22^{\circ} \mathrm{S}\right)$. Cont Shelf Res 89:5-14. https://doi.org/10.1016/j. csr.2013.11.003

Davis SM, Rosenlof KH (2012) A multidiagnostic intercomparison of tropical-width time series using reanalyses and satellite observations. J Clim 25(4):1061-1078. https://doi.org/10.1175/JCLID-11-00127.1

de Souza MM, Mathis M, Pohlmann T (2019) Driving mechanisms of the variability and long-term trend of the Brazil-Malvinas confluence during the 21st century. Clim Dyn 53:6453-6468. https://doi. org/10.1007/s00382-019-04942-7

Harley CD, Hughes AR, Hultgren KM, Miner BG, Sorte CJ, Thornber CS, Rodriguez LF, Tomanek L, Williams SL (2006) The impacts of climate change in coastal marine systems. Ecol Lett 9(2):228241. https://doi.org/10.1111/j.1461-0248.2005.00871.x

Hein H, Hein B, Pohlmann T, Long BH (2013) Inter-annual variability of upwelling off the South-Vietnamese coast and its relation to nutrient dynamics. Global and Planetary Change 110:170-182. https://doi.org/10.1016/j.gloplacha.2013.09.009

$\mathrm{Hu}$ Y, Huang H, Zhou C (2018) Widening and weakening of the Hadley circulation under global warming. Sci Bull 63(10):640-644. https ://doi.org/10.1016/j.scib.2018.04.020

IPCC (2013) The physical science basis. Contribution of working group I to the fifth assessment report of the intergovernmental 
panel on climate change. Cambridge University Press, Cambridge, UK and New York, NY, USA, https://doi.org/10.1017/CBO97 81107415324.015 , arXiv: $1011.1669 \mathrm{v} 3$

IPCC (2014) Climate Change 2014: Synthesis Report. Contribution of Working Groups I, II and III to the Fifth Assessment Report of the Intergovernmental Panel on Climate Change [Core Writing Team, R.K. Pachauri and L.A. Meyer (eds)]. IPCC, Geneva, Switzerland, $151 \mathrm{pp}$

Kalnay E, Kanamitsu M, Kistler R, Collins W, Deaven D, Gandin L, Iredell M, Saha S, White G, Woollen J, Zhu Y, Chelliah M, Ebisuzaki W, Higgins W, Janowiak J, Mo KC, Ropelewski C, Wang J, Leetmaa A, Reynolds R, Jenne R, Joseph D (1996) The NCEP/NCAR 40-year reanalysis project. Bull Am Meteorol Soc 77(3):437-471, https://doi.org/10.1175/15200477(1996)077<0437:TNYRP>2.0.CO;2, arXiv:1011.1669v3

Kang SM, Lu J (2012) Expansion of the Hadley cell under global warming: Winter versus summer. Journal of Climate 25(24):83878393. https://doi.org/10.1175/JCLI-D-12-00323.1

Kushner PJ, Held IM, Delworth TL (2000) Southern hemisphere atmospheric circulation response to global warming. J Clim 14:2238-2249

Levitus S (1983) Climatological Atlas of the World Ocean. Eos, Transactions American Geophysical Union 64(49):962-963. https://doi. org/10.1029/EO064i049p00962-02

Lima ID, Garcia CA, Möller OO (1996) Ocean surface processes on the Southern Brazilian shelf: characterization and seasonal variability. Cont Shelf Res 16(10):1307-1317. https://doi.org/10.1016/02784343(95)00066-6

Lorenz EN (1955) Available Potential Energy and the Maintenance of the General Circulation. Tellus 7(2):157-167. https://doi. org/10.3402/tellusa.v7i2.8796

Ma Giorgetta, Jungclaus JH, Reick CH, Legutke S, Bader J, Böttinger M, Brovkin V, Crueger T, Esch M, Fieg K, Glushak K, Gayler V, Haak H, Hollweg HD, Ilyina T, Kinne S, Kornblueh L, Matei D, Mauritsen T, Mikolajewicz U, Mueller W, Notz D, Pithan F, Raddatz T, Rast S, Redler R, Roeckner E, Schmidt H, Schnur R, Segschneider J, Six KD, Stockhause M, Timmreck C, Wegner J, Widmann H, Wieners KH, Claussen M, Marotzke J, Stevens B (2013) Climate and carbon cycle changes from 1850 to 2100 in MPI-ESM simulations for the coupled model intercomparison project phase 5. J Adv Model Earth Syst 5(3):572-597. https:// doi.org/10.1002/jame. 20038

Mathis M, Elizalde A, Mikolajewicz U (2018) Which complexity of regional climate system models is essential for downscaling anthropogenic climate change in the Northwest European Shelf? Clim Dyn 50(7-8):2637-2659. https://doi.org/10.1007/s0038 2-017-3761-3

Miranda PM, Alves JM, Serra N (2013) Climate change and upwelling: response of Iberian upwelling to atmospheric forcing in a regional climate scenario. Clim Dyn 40(11-12):2813-2824. https://doi. org/10.1007/s00382-012-1442-9

Möller OO, Piola AR, Freitas AC, Campos EJ (2008) The effects of river discharge and seasonal winds on the shelf off southeastern South America. Cont Shelf Res 28(13):1607-1624. https://doi. org/10.1016/j.csr.2008.03.012

Oke PR, Middleton JH (2000) Topographically induced upwelling off Eastern Australia. J Phys Oceanogr 30(3):512-531. https://doi. org/10.1175/1520-0485(2000)030<0512:TIUOEA > 2.0.CO;2

Oliveira LR, Piola AR, Mata MM, Soares ID (2009) Brazil Current surface circulation and energetics observed from drifting buoys. J Geophys Res Oceans 114(10):1-12. https://doi.org/10.1029/2008J C004900

Palma ED, Matano RP (2009) Disentangling the upwelling mechanisms of the South Brazil Bight. Cont Shelf Res 29:1525-1534. https://doi.org/10.1016/j.csr.2009.04.002. arXiv:1209.1653v1
Pimenta FM, Campos EJD, Miller JL, Piola AR (2005) A numerical study of the Plata River plume along the southeastern South American continental shelf. Braz J Oceanogr 53(3-4):129-146. https://doi.org/10.1590/s1679-87592005000200004

Piola AR, Matano RP, Palma ED, Möller OO, Campos EJ (2005) The influence of the Plata River discharge on the western South Atlantic shelf. Geophys Res Lett 32(1):1-4. https://doi. org/10.1029/2004GL021638

Piola AR, Palma ED, Bianchi AA, Castro BM, Dottori M, Guerrero RA, Marrari M, Matano RP, Möller OO, Saraceno M (2018) Physical oceanography of the SW Atlantic Shelf: a review. Springer International Publishing, Cham, pp 37-56

Pohlmann T (1996) Predicting the thermocline in a circulation model of the North Sea - Part i: model description, calibration and verification. Cont Shelf Res 16(2):131-146. https://doi.org/10.1016/02784343(95)90885-S

Pohlmann T (2006) A meso-scale model of the central and southern North Sea: consequences of an improved resolution. Cont Shelf Res 26:2367-2385. https://doi.org/10.1016/j.csr.2006.06.011

Praveen V, Ajayamohan RS, Valsala V, Sandeep S (2016) Intensification of upwelling along Oman coast in a warming scenario. Geophys Res Lett 43(14):7581-7589. https://doi.org/10.1002/2016G L069638

Rykaczewski RR, Dunne JP, Sydeman WJ, García-reyes M, Black BA, Bograd SJ (2015) Poleward displacement of coastal upwellingfavorable winds in the ocean's eastern boundary currents through the 21 st century. Geophys Res Lett 42:6424-6431. https://doi. org/10.1002/2015GL064694

Silveira ICA, Schmidt ACK, Campos EJD, de Godoi SS, Ikeda Y (2000) A corrente do Brasil ao largo da costa leste brasileira. Revista Brasileira de Oceanografia 48(2):171-183. https://doi. org/10.1590/S1413-77392000000200008

Snyder MA, Sloan LC, Diffenbaugh NS, Bell JL (2003) Future climate change and upwelling in the California Current. Geophys Res Lett 30(15):1-4. https://doi.org/10.1029/2003GL017647

Song YT, Chao Y (2004) A theoretical study of topographic effects on coastal upwelling and cross-shore exchange. Ocean Model 6:151-176. https://doi.org/10.1016/S1463-5003(02)00064-1

Sousa MC, Alvarez I, DeCastro M, Gomez-Gesteira M, Dias JM (2017) Seasonality of coastal upwelling trends under future warming scenarios along the southern limit of the canary upwelling system. Prog Oceanogr 153:16-23. https://doi.org/10.1016/j.pocea n.2017.04.002

Su J, Pohlmann T (2009) Wind and topography influence on an upwelling system at the eastern Hainan coast. J Geophys Res Oceans 114(6):1-19. https://doi.org/10.1029/2008JC005018

Swart NC, Fyfe JC (2012) Observed and simulated changes in the Southern Hemisphere surface westerly wind-stress. Geophys Res Lett 39(16):6-11. https://doi.org/10.1029/2012GL052810

Sydeman WJ, Schoeman DS, Rykaczewski RR, Thompson SA, Black BA, Bograd SJ (2014) Climate change and wind intensification in coastal upwelling ecosystems. Science 345(6192):77-80

Urakawa LS, Hasumi H (2009) The energetics of global thermohaline circulation and its wind enhancement. J Phys Oceanogr 39(7):1715-1728. https://doi.org/10.1175/2009JPO4073.1

Urakawa LS, Saenz JA, Hogg AM (2013) Available potential energy gain from mixing due to the nonlinearity of the equation of state in a global ocean model. Geophys Res Lett 40(10):2224-2228. https://doi.org/10.1002/grl.50508

Varela R, Lima FP, Seabra R, Meneghesso C, Gómez-Gesteira M (2018) Coastal warming and wind-driven upwelling: a global analysis. Sci Total Environ 639:1501-1511. https://doi.org/10.1016/j. scitotenv.2018.05.273

Wang M, Overland JE, Bond NA (2010) Climate projections for selected large marine ecosystems. J Mar Syst 79(3-4):258-266. https://doi.org/10.1016/j.jmarsys.2008.11.028 
Wang D, Gouhier TC, Menge BA, Ganguly AR (2015) Intensification and spatial homogenization of coastal upwelling under climate change. Nature 518(7539):390-394. https://doi.org/10.1038/natur e14235

Wilcox LJ, Charlton-Perez AJ, Gray LJ (2012) Trends in Austral jet position in ensembles of high- and low-top CMIP5 models. J Geophys Res Atmos 117(13):1-10. https://doi.org/10.1029/2012J D017597
Publisher's Note Springer Nature remains neutral with regard to jurisdictional claims in published maps and institutional affiliations. 